\title{
Perbandingan Mannitol 20\%, NaCl 3\% dan Natrium Laktat Hipertonik terhadap Osmolaritas dan Brain Relaxation Score Pasien Tumor Otak yang menjalani Kraniotomi Pengangkatan Tumor
}

\author{
Dear Mohtar Wirawijaya, Ruli Herman Sitanggang, Tatang Bisri \\ Departemen Anestesiologi dan Terapi Intensif \\ Fakultas Kedokteran Universitas Padjadjaran/RSUP Dr. Hasan Sadikin Bandung
}

\begin{abstract}
Abstrak
Latar Belakang dan Tujuan: Mannitol membuat relaksasi otak, namun memiliki efek samping berkurangnya volume intravaskuler, peningkatan kembali tekanan intrakranial (rebound) dan gagal ginjal. Penggunaan $\mathrm{NaCl} 3 \%$ dan natrium laktat hipertonik dapat memberikan relaksasi otak yang baik. Tujuan penelitian ini untuk mengetahui peningkatan osmolaritas dan brain relaxation score (BRS) pada pasien yang menjalani kraniotomi pengangkatan tumor dengan menggunakan mannitol 20\%, $\mathrm{NaCl} 3 \%$, dan matrium laktat hipertonik.

Subjek dan Metode: Penelitian merupakan uji klinik terkontrol secara acak terhadap 39 pasien tumor otak yang masing-masing mendapatkan 2,5cc/kgBB mannitol 20\%, $\mathrm{NaCl} 3 \%$, dan natrium laktat hipertonik.

Hasil: Tidak ada perbedaan peningkatan osmolaritas yang signifikan antara ketiga kelompok 1 jam setelah pemberian osmoterapi dan saat durameter dibuka ( $p>0,05)$. BRS pada ketiga kelompok memiliki nilai median yang sama besar $(2,00)$, artinya tidak ada perbedaan BRS yang bermakna $(p>0,05)$. Terdapat peningkatan diuresis yang signifikan pada pemberian mannitol $20 \%$, peningkatan klorida pada $\mathrm{NaCl} 3 \%$ dan peningkatan glukosa signifikan pada natrium laktat hipertonik.

Simpulan: Mannitol 20\%, $\mathrm{NaCl} \mathrm{3 \%}$, dan natrium laktat hipertonik memberikan relaksasi otak yang sama dan tidak mengakibatkan perbedaan osmolaritas yang signifikan.
\end{abstract}

Kata kunci: Brain relaxation score, kraniotomi, mannitol, $\mathrm{NaCl}$ 3\%, natrium laktat hipertonik, osmolaritas

JNI 2018;7 (1): 1-10

Comparison Between 20\% Mannitol, 3\% NaCl and Hypertonic Sodium Lactate on Osmolarity and Brain Relaxation Score Brain Tumor Patient underwent Craniotomy Tumor Removal

\begin{abstract}
Background and Objective: Mannitol produce brain relaxation but associated with several side effects such as reduced intravascular volume, rebound in intracranial pressure and kidney failure. The use of $3 \% \mathrm{NaCl}$ and hypertonic sodium lactate (HSL) may provide brain relaxation. Aim of this study is to examine increased osmolarity and brain relaxation score (BRS) in patient underwent craniotomy using $20 \%$ mannitol, $3 \% \mathrm{NaCl}$, and hypertonic sodium lactate.

Subject and Method: This is a randomized control study of 39 brain tumor patients divided into three groups each obtained $2.5 \mathrm{cc} / \mathrm{kg} 20 \%$ mannitol, $3 \% \mathrm{NaCl}$, and HSL.

Result: there is no significant difference of osmolarity between the three groups 1 hour after administration of osmotherapy and during the opening of durameter $(p>0,05)$. BRS between the three groups have an equivalent median score $(2,00)$, it means no significant difference in BRS $(p>0,05)$. A significantly increased diuresis in the administration of $20 \%$ mannitol, increased chloride to $3 \% \mathrm{NaCl}$ and significant glucose increase in HSL.

Conclusion: Administration of $20 \%$ mannitol, $3 \% \mathrm{NaCl}$ and $\mathrm{HSL}$ produce the same brain relaxation and resulted in insignificant osmolarity differences.
\end{abstract}

Key words: Brain relaxation score, craniotomy, hypertonic sodium lactate, $20 \%$ mannitol, 3\% NaCl, osmolarity

JNI 2018;7 (1): 1-10 


\section{Pendahuluan}

Otak yang relaks saat pembedahan merupakan hal penting untuk memudahkan manipulasi bedah, meminimalisir kerusakan jaringan otak yang sehat saat operasi serta meningkatkan luaran neurologik pasien. Peningkatan tekanan intrakranial dapat mengakibatkan otak yang tegang intraoperatif. Penatalaksanaan edema serebral dan peningkatan tekanan intrakranial dengan osmoterapi merupakan komponen penting dalam manajemen perioperatif dalam bedah saraf. ${ }^{1}$

Pemberian osmoterapi saat kraniotomi sebelum duramater dibuka adalah intervensi yang dilakukan untuk membuat relaksasi otak pada operasi intrakranial. Osmolaritas merupakan penentu utama perpindahan air melalui sawar darah otak yang intak. Bila kita meningkatkan osmolaritas serum, jaringan otak normal akan mengalami dehidrasi sehingga volume otak dan tekanan intrakranial (TIK) akan menurun. ${ }^{1,2}$ Mannitol telah menjadi pilihan utama osmoterapi pada peningkatan TIK. Mannitol bekerja dengan membuat perbedaan tekanan osmotik, autoregulasi, viskositas darah menjadi lebih encer sehingga pengeluaran $\mathrm{CO}_{2}$ menjadi lebih baik, dan mengurangi volume cairan serebrospinal. Walaupun demikian, mannitol dapat berhubungan dengan efek samping yang berat, seperti berkurangnya volume intravaskular (hingga syok), peningkatan kembali TIK (rebound), hipokalemia, hemolisis, hiperosmolaritas dan gagal ginjal..$^{1-4}$

Selain mannitol, $\mathrm{NaCl} 3 \%$ dapat menurunkan TIK dan meningkatkan tekanan perfusi serebral dengan efektifitas yang sama seperti mannitol., $\mathrm{NaCl}$ 3\% memiliki keuntungan dibanding dengan mannitol pada pasien yang hipovolemik atau hipotensif, atau pada situasi lain seperti gagal ginjal, osmolaritas serum $>320 \mathrm{mOsm} / 1$. Efek ini didapatkan bukan hanya karena efek osmotiknya yang menurunkan cairan intraserebral namun memiliki komponen hemodinamik yang menguntungkan (seperti pada pasien cedera otak traumatik dengan syok), yaitu meningkatkan cairan ekstraseluler, curah jantung, dan tekanan arteri rerata yang akan meningkatkan aliran darah serebral dan oksigenasi serebral. Efek samping penggunaan $\mathrm{NaCl} 3 \%$ diantaranya adalah peningkatan kembali TIK (rebound), hipokalemia, myelinolisis pontin sentral, kelebihan cairan akut, gagal ginjal, gagal jantung atau edema paru. ${ }^{2}$ Adanya anion klorida yang tidak dimetabolisme pada penggunaan $\mathrm{NaCl}$ hipertonik dapat menimbulkan hal yang tidak diinginkan seperti penurunan strong ion difference (SID) dan meningkatkan derajat disosiasi air dan menimbulkan asidosis metabolik. ${ }^{7}$

Berbagai penelitian telah dilakukan untuk membandingkan penggunaan mannitol dan $\mathrm{NaCl}$ $3 \%$. Kedua osmoterapi tersebut telah dibuktikan efektif untuk mengontrol TIK melalui mekanisme yang berbeda; dehidrasi osmotik interstitium serebral, penurunan viskositas darah, peningkatan sel darah merah, dan perbaikan mikrosirkulasi. Penelitian prospektif dengan randomisasi buta ganda di India dan Amerika terhadap pasien yang menjalanioperasi kraniotomi elektifmenunjukkan $\mathrm{NaCl}$ 3\% memberikan efek relaksasi otak yang sama dibanding dengan mannitol dan mempunyai efek diuresis yang lebih sedikit. ${ }^{8,9}$

Penggunaan cairan hipertonis lain untuk osmoterapi yang digunakan saat ini adalah atrium laktat hipertonik. Laktat dikenal sebagai kunci metabolit interseluler atau interorgan antara glikolisis dan fosforilasi oksidatif yang dapat diproduksi dan digunakan oleh otak dalam kondisi patologis. Penelitian pada hewan dan manusia menunjukkan bahwa laktat dapat mencegah efek neurologis hipoglikemia, mengindikasikan bahwa laktat sistemik dapat dimetabolisme oleh otak. Sebuah data eksperimental pada hipokampus tikus yang mengalami reperfusi iskemia menunjukkan bahwa laktat merupakan substrat yang lebih baik dari glukosa. Natrium laktat hipertonik juga memberikan fungsi kognitif yang lebih baik secara signifikan pada tikus 10-15 hari setelah cedera otak traumatik dibandingkan dengan $\mathrm{NaCl}$ hipertonik. ${ }^{7,8}$

Sebuah penelitian yang dilakukan di Makasar terhadap pasien yang menjalani kraniotomi pada tahun 2012 membandingkan efektivitas $\mathrm{Na}$ laktat hipertonik dan mannitol terhadap 
relaksasi otak dan kadar glukosa. Penelitian tersebut menunjukkan bahwa $\mathrm{Na}$ laktat hipertonik memberikan relaksasi otak yang sama dibanding dengan mannitol namun dengan profil hemodinamik yang lebih stabil tetapi disertai peningkatan kadar glukosa yang signifikan. ${ }^{7}$

Penelitian ini bertujuan untuk membandingkan pengaruh mannitol $20 \%, \mathrm{NaCl} 3 \%$, dan Na laktat hipertonik terhadap peningkatan osmolaritas plasma dan Brain Relaxation Score (BRS) pada pasien tumor otak yang menjalani operasi kraniotomi pengangkatan tumor. Sampai saat ini belum ada penelitian yang membandingkan ketiga osmoterapi tersebut secara bersamaan untuk meningkatkan osmolaritas plasma dan pada operasi kraniotomi pengangkatan tumor.

\section{Subjek dan Metode}

Penelitian ini merupakan penelitian randomized controlled trial (RCT) dengan randomisasi permutasi blok mengenai peningkatan osmolaritas plasma dan BRS pada kraniotomi pengangkatan tumor. Subjek penelitian adalah pasien tumor otak yang menjalani kraniotomi pengangkatan tumor di RSUP Dr. Hasan Sadikin Bandung. Penelitian dilakukan dari bulan Februari 2017 sampai dengan Mei 2017. Kriteria inklusi subjek penelitian ini adalah pasien dengan tumor intrakranial yang menjalani operasi kranotomi pengangkatan tumor, status fisik berdasarkan American Society of Anesthesiologist (ASA) dalam kategori I dan II, usia pasien antara 18 sampai dengan 65 tahun, Glasgow Coma Scale $>13$, pasien tidak memiliki gangguan ginjal dan kardiovaskular sebelumnya. Subjek penelitian dieksklusi pada pasien dengan riwayat alergi terhadap obat-obatan yang digunakan dalam penelitian, riwayat operasi intrakranial sebelumnya, hiponatremia atau hipernatremia sebelumnya, dan riwayat penggunaan terapi hiperosmolar kurang dari 24 jam. Pada penelitian ini desain yang digunakan adalah analitis kategorik numerik tidak berpasangan. Penentuan besar sampel dilakukan berdasarkan perhitungan statistik, dengan menetapkan taraf kepercayaan 95\% dan kuasa uji (power test) 80\%; dianggap bermakna bila nilai $\mathrm{p}<0,05$. Perhitungan jumlah sampel minimal untuk masing-masing kelompok adalah 13 orang. Total sampel untuk 3 kelompok adalah 39 orang. Pemilihan subjek penelitian berdasarkan consecutive sampling, yaitu urutan datang pasien yang memenuhi kriteria inklusi dan tidak termasuk kriteria ekslusi serta besar sampel minimal. Alokasi subjek ke dalam perlakuan berdasarkan permutasi blok.

Subjek penelitian sebanyak 39 subjek dibagi menjadi 3 kelompok yang dilakukan secara acak menggunakan blok permutasi, yaitu kelompok A mendapatkan mannitol $20 \%$ dosis $2,5 \mathrm{~mL} /$ $\mathrm{kgBB}$ intravena terdiri atas 13 subjek, kelompok B mendapatkan $\mathrm{NaCl} 3 \%$ dosis $2,5 \mathrm{~mL} / \mathrm{kgBB}$ intravena terdiri atas 13 subjek dan kelompok C mendapatkan natrium laktat hipertonik dosis 2,5 $\mathrm{mL} / \mathrm{kgBB}$ intravena terdiri atas 13 subjek. Setelah mendapat persetujuan dari Komite Etik Penelitian Kesehatan Fakultas Kedokteran Universitas Padjadjaran/RSUP Dr. Hasan Sadikin Bandung, dilakukan informed consent kepada pasien mengenai pembedahan dan penelitian yang akan dilaksanakan. Pasien yang sesuai kriteria dan telah menandatangani informed consent dijadikan sebagai subjek penelitian. Semua pasien yang ikut serta dalam penelitian ini diinfus dengan Ringerfundin $2 \mathrm{~mL} / \mathrm{kg} / \mathrm{jam}$ sebelum masuk ke kamar operasi. Setelah masuk ke kamar operasi, dipasang alat-alat untuk memantau tekanan darah non invasif, elektrokardiogram, saturasi oksigen, dan suhu. Pemasangan akses vena sentral dan jalur arteri dilakukan sesuai dengan indikasi. Preoksigenasi dilakukan selama 5 menit dengan oksigen $100 \%$ sebelum induksi dimulai. Induksi dilakukan dengan lidokain 1,5 mg/kgBB, fentanil $3 \mathrm{mcg} / \mathrm{kgBB}$, thiopental $5 \mathrm{mg} / \mathrm{kgBB}$, dan rokuronium $1 \mathrm{mg} / \mathrm{kgBB}$, setelah itu volatil isofluran/sevofluran dibuka 1 MAC. Intubasi dilakukan dengan laringoskopi direk. Setelah intubasi, dipasang monitor $\mathrm{EtCO}_{2}$ dan dilakukan pengambilan sampel darah untuk menghitung osmolaritas plasma. Dengan menggunakan 3 amplop, pasien akan mendapatkan salah satu dari osmoterapi yang diberikan setelah induksi dengan dosis $2,5 \mathrm{~mL} / \mathrm{kgBB}$ dalam waktu 15 30 mnt. Rumatan anestesi diberikan dengan volatil isofluran atau sevofluran 1 MAC dengan $\mathrm{O}_{2}$ dan udara, ditambah dengan thiopental 
kontinu dengan dosis $1-3 \mathrm{mg} / \mathrm{kgBB} / \mathrm{jam}$ serta rokuronium kontinu $10 \mathrm{mcg} / \mathrm{kgBB} / \mathrm{menit}$. Pemantauan hemodinamik dilakukan setiap 5 menit. Setelah induksi dilakukan pemasangan kateter urine untuk memantau diuresis dan balans cairan. Rumatan cairan diberikan $1,5 \mathrm{cc} / \mathrm{kgBB} /$ jam. Selama operasi $\mathrm{EtCO}_{2}$ dipertahankan 25-30 $\mathrm{mmHg}$ dan Saturasi $\mathrm{O}_{2}$ dipertahankan $98-99 \%$. Tekanan arteri rerata dipertahankan 20\% dari nilai dasar. Episode hipotensi (penurunan tekanan arteri rerata $20 \%$ dari nilai dasar atau sistolik < $90 \mathrm{mmHg}$ ) diterapi dengan 5-10 mg ephedrine. Relaksasi otak dilihat oleh operator yang telah dilakukan evaluasi tentang tatacara penilaian BRS agar terdapat penilaian yang sama terhadap BRS. Penilaian BRS dengan skala 4 poin, yaitu: $1=$ Relaks sempurna (parenkim otak tidak melekat pada duramater); $2=$ Cukup relaks (parenkim otak melekat pada duramater namun masih relaks); $3=$ Tegang (parenkim otak sedikit menonjol);
4=Cembung (parenkim otak menonjol ke luar duramater). Bila ketegangan otak mengganggu manipulasi surgikal diberikan furosemid $20 \mathrm{mg}$ intravena atau ekstra manitol $20 \%$ sebanyak $0,25 \mathrm{~g} / \mathrm{kgBB}$ sebagai rescue. Pengambilan darah untuk pemeriksaan osmolaritas plasma dilakukan sebelum pemberian osmoterapi, 1 jam setelah pemberian osmoterapi, dan saat duramater dibuka. Semua data yang diperoleh dicatat dalam formulir khusus dan dianalisis secara statistika.

Karakteristik umum, peningkatan osmolaritas plasma, BRS dan hasil temuan lain dideskripsikan dalam bentuk tabel distribusi frekuensi yang menampilkan jumlah (n), rerata, standar deviasi (SD), dan persentase (\%). Untuk data numerik nilai p diuji dengan One Way Anova apabila data terdistribusi normal dan alternatif uji Kruskal Wallis apabila data tidak terdistribusi normal. Data kategorik nilai $p$ dihitung berdasarkan uji

Tabel 1 Karakteristik Umum Subjek Penelitian

\begin{tabular}{|c|c|c|c|c|}
\hline \multirow[b]{2}{*}{ Variabel } & \multicolumn{3}{|c|}{ Kelompok } & \multirow[b]{2}{*}{ Nilai $p$} \\
\hline & $\begin{array}{c}\text { Mannitol 20\% } \\
\mathrm{N}=13\end{array}$ & $\begin{array}{l}\mathrm{NaCl} \mathrm{3 \%} \\
\mathrm{N}=13\end{array}$ & $\begin{array}{c}\text { Natrium Laktat } \\
\text { Hipertonik } \\
\mathrm{N}=13\end{array}$ & \\
\hline \multicolumn{5}{|l|}{ Umur (th) } \\
\hline Mean \pm Std & $39,53 \pm 9,896$ & $44,61 \pm 9,421$ & $42,30 \pm 8,547$ & 0,389 \\
\hline \multicolumn{5}{|l|}{ Jenis kelamin } \\
\hline Laki-laki & $2 / 13$ & $1 / 13$ & $2 / 13$ & 0,795 \\
\hline Perempuan & $11 / 13$ & $12 / 13$ & $11 / 13$ & \\
\hline \multicolumn{5}{|l|}{ Lokasi Tumor } \\
\hline Supratentorial & $12 / 13$ & $12 / 13$ & $11 / 13$ & 0,757 \\
\hline Infratentorial & $1 / 13$ & $1 / 13$ & $2 / 13$ & \\
\hline \multicolumn{5}{|l|}{ Diagnosis Klinis } \\
\hline Astrositoma & $1 / 13$ & $0 / 13$ & $0 / 13$ & 0,628 \\
\hline Glioma & $3 / 13$ & $2 / 13$ & $2 / 13$ & \\
\hline Meningioma & $9 / 13$ & $10 / 13$ & $9 / 13$ & \\
\hline Schwannoma & $0 / 13$ & $1 / 13$ & $2 / 13$ & \\
\hline $\begin{array}{l}\text { Rerata } \\
(\mathrm{mmHg})\end{array}$ & & & & \\
\hline $\operatorname{Mean} \pm \operatorname{Std}$ & $84,75 \pm 3,453$ & $83,94 \pm 4,849$ & $86,82 \pm 4,177$ & 0,213 \\
\hline
\end{tabular}

Keterangan: MAP, Mean arterial pressure; untuk data numerik nilai $p$ diuji dengan uji One Way Anova apabila data berdsitribusi normal, dengan alternatif uji Kruskal Wallis apabila data tidak berdistribusi normal. Data kategorik nilai p dihitung berdasarkan uji Chi-Square dengan alternatif uji Kolmogorov Smirnov dan Exact Fisher apabila syarat dari Chi-Square tidak terpenuhi. Nilai kemaknaan berdasarkan nilai $\mathrm{p}<0,05$. Tanda* menunjukkan nilai $\mathrm{p}<0,05$ artinya signifkan atau bermakna secara statistik. 
Tabel 2. Perbandingan Osmolaritas Plasma pada Ketiga Kelompok Osmoterapi

\begin{tabular}{|c|c|c|c|c|}
\hline \multirow[b]{2}{*}{ Osmolaritas } & \multicolumn{3}{|c|}{ Kelompok } & \multirow[b]{2}{*}{ Nilai p } \\
\hline & $\begin{array}{l}\text { Mannitol } 20 \% \\
\quad \mathrm{~N}=13\end{array}$ & $\begin{array}{l}\mathrm{NaCl} 3 \% \\
\mathrm{~N}=13\end{array}$ & $\begin{array}{c}\text { Natrium Laktat } \\
\text { Hipertonik } \\
\mathrm{N}=13\end{array}$ & \\
\hline \multicolumn{5}{|l|}{$\begin{array}{l}\text { Sebelum pemberian } \\
\text { Osmoterapi }(\mathrm{mOsm} / \mathrm{L})\end{array}$} \\
\hline Mean \pm Std & $291,27 \pm 4,332$ & $288,86 \pm 3,828$ & $290,01 \pm 4,894$ & 0,381 \\
\hline \multicolumn{5}{|l|}{$\begin{array}{l}1 \text { Jam setelah pemberian } \\
\text { Osmoterapi }(\mathrm{mOsm} / \mathrm{L})\end{array}$} \\
\hline Mean \pm Std & $291,73 \pm 4,879$ & $293,876 \pm 4,151$ & $293,33 \pm 6,302$ & 0,556 \\
\hline $\begin{array}{l}\text { Saat Duramater Dibuka } \\
(\mathrm{mOsm} / \mathrm{L})\end{array}$ & & & & \\
\hline Mean \pm Std & $295,34 \pm 6,944$ & $297,77 \pm 3,895$ & $296,40 \pm 7,752$ & 0,629 \\
\hline \multicolumn{5}{|c|}{$\begin{array}{l}\text { Keterangan: untuk data numerik nilai } \mathrm{p} \text { diuji dengan uji One Way Anova apabila data berdsitribusi normal, } \\
\text { dengan alternatif uji Kruskal Wallis apabila data tidak berdistribusi normal. Data kategorik nilai p dihitung } \\
\text { berdasarkan uji Chi-Square dengan alternatif uji Kolmogorov Smirnov dan Exact Fisher apabila syarat dari } \\
\text { Chi-Square tidak terpenuhi. Nilai kemaknaan berdasarkan nilai } \mathrm{p}<0,05 \text {. Tanda* menunjukkan nilai } \mathrm{p}<0,05 \\
\text { artinya signifkan atau bermakna secara statistik. }\end{array}$} \\
\hline
\end{tabular}

Tabel 3. Perbandingan Brain Relaxation Score pada Ketiga Kelompok Osmoterapi

\begin{tabular}{|c|c|c|c|c|}
\hline \multicolumn{5}{|c|}{ Kelompok } \\
\hline Variabel & $\begin{array}{l}\text { Mannitol 20\% } \\
\qquad \mathrm{N}=13\end{array}$ & $\begin{array}{c}\mathrm{NaCl} 3 \% \\
\mathrm{~N}=13\end{array}$ & $\begin{array}{l}\text { Natrium Laktat } \\
\text { Hipertonik } \\
\mathrm{N}=13\end{array}$ & Nilai $p$ \\
\hline \multicolumn{5}{|l|}{$\begin{array}{l}\text { Brain Relaxation } \\
\text { score }\end{array}$} \\
\hline Median & 2,00 & 2,00 & 2,00 & 0,224 \\
\hline $\begin{array}{l}\text { Range (min- } \\
\max )\end{array}$ & $1,00-3,00$ & $1,00-3,00$ & $1,00-4,00$ & \\
\hline
\end{tabular}

Keterangan: untuk data numerik nilai p diuji dengan uji One Way Anova apabila data berdsitribusi normal, dengan alternatif uji Kruskal Wallis apabila data tidak berdistribusi normal. Data kategorik nilai p dihitung berdasarkan uji Chi-Square dengan alternatif uji Kolmogorov Smirnov dan Exact Fisher apabila syarat dari Chi-Square tidak terpenuhi. Nilai kemaknaan berdasarkan nilai $\mathrm{p}<0,05$. Tanda* menunjukkan nilai $\mathrm{p}<0,05$ artinya signifkan atau bermakna secara statistik

Chi-Square dengan alternatif uji Kolmogorov Smirnov dan Exact Fisher apabila syarat dari Chi-Square tidak terpenuhi. Nilai kemaknaan berdasarkan nilai $\mathrm{p}<0,05$ artinya signifkan atau bermakna secara statistik. Data yang diperoleh dicatat dalam formulir khusus kemudian diolah dengan program Stastitical Product and Service Solutions (SPSS) versi 21.0 for Windows.

\section{Hasil}

Penelitian dilakukan terhadap 39 pasien tumor otak yang menjalani kraniotomi pengangkatan tumor di Central Operating Theatre (COT) RSUP Dr. Hasan Sadikin Bandung. Hasil analisis statistik (Tabel 1) menunjukkan bahwa karakteristik umum subjek penelitian, yaitu usia, jenis kelamin, lokasi tumor, diagnosis klinis dan rerata Mean arterial 
pressure (MAP) pada ketiga kelompok tidak terdapat perbedaan yang bermakna $(\mathrm{p}>0,05)$. Pada ketiga kelompok tidak terdapat perbedaan rerata yang signifikan secara statistika antara osmolaritas plasma sebelum pemberian osmoterapi, 1 jam setelah pemberian osmoterapi, dan saat durameter dibuka ( $>0,05$; Tabel 2). Penilaian BRS pada mannitol 20\%, $\mathrm{NaCl} 3 \%$, dan

Tabel 4. Perbandingan Nilai Klorida pada Ketiga Kelompok Osmoterapi

\begin{tabular}{|c|c|c|c|c|}
\hline \multicolumn{5}{|c|}{ Kelompok } \\
\hline Klorida & $\begin{array}{l}\text { Mannitol } 20 \% \\
\qquad \mathrm{~N}=13\end{array}$ & $\begin{array}{c}\mathrm{NaCl} 3 \% \\
\mathrm{~N}=13\end{array}$ & $\begin{array}{c}\text { Natrium Laktat } \\
\text { Hipertonik } \\
\mathrm{N}=13\end{array}$ & Nilai $p$ \\
\hline $\begin{array}{l}\text { Sebelum } \\
\text { pemberian } \\
\text { Osmoterapi } \\
(\mathrm{meq} / \mathrm{L})\end{array}$ & & & & \\
\hline $\begin{array}{l}\text { Mean } \pm \text { Std } \\
1 \text { Jam setelah } \\
\text { pemberian } \\
\text { Osmoterapi } \\
(\mathrm{meq} / \mathrm{L})\end{array}$ & $103,00 \pm 4,082$ & $104,92 \pm 3,303$ & $102,69 \pm 3,351$ & 0,179 \\
\hline Mean \pm Std & $103,07 \pm 4,071$ & $107,69 \pm 3,923$ & $102,53 \pm 3,799$ & $0,003 * *$ \\
\hline $\begin{array}{l}\text { Saat Duramater } \\
\text { Dibuka }(\mathrm{meq} / \mathrm{L})\end{array}$ & & & & \\
\hline Mean \pm Std & $102,38 \pm 2,328$ & $109,07 \pm 3,904$ & $103.07 \pm 3,662$ & $0,000 * *$ \\
\hline
\end{tabular}

Keterangan: untuk data numerik nilai p diuji dengan uji One Way Anova apabila data berdsitribusi normal, dengan alternatif uji Kruskal Wallis apabila data tidak berdistribusi normal. Data kategorik nilai p dihitung berdasarkan uji Chi-Square dengan alternative uji Kolmogorov Smirnov dan Exact Fisher apabila syarat dari Chi-Square tidak terpenuhi. Nilai kemaknaan berdasarkan nilai $\mathrm{p}<0,05$. Tanda* menunjukkan nilai $\mathrm{p}<0,05$ artinya signifkan atau bermakna secara statistik.

Tabel 5. Perbandingan Nilai Glukosa Darah pada Ketiga Kelompok Osmoterapi

\begin{tabular}{|c|c|c|c|c|}
\hline \multirow[t]{2}{*}{ Glukosa Darah (mg/dL) } & \multicolumn{3}{|c|}{ Kelompok } & \multirow[b]{2}{*}{ Nilai $\mathrm{p}$} \\
\hline & $\begin{array}{l}\text { Mannitol 20\% } \\
\mathrm{N}=13\end{array}$ & $\begin{array}{l}\mathrm{NaCl} 3 \% \\
\mathrm{~N}=13\end{array}$ & $\begin{array}{l}\text { Natrium Laktat } \\
\text { Hipertonik } \\
\mathrm{N}=13\end{array}$ & \\
\hline \multicolumn{5}{|c|}{ sebelum pemberian Osmoterapi } \\
\hline Mean \pm Std & $106,69 \pm 25,965$ & $109,23 \pm 22,023$ & $109,46 \pm 21,838$ & 0,945 \\
\hline \multicolumn{5}{|l|}{$\begin{array}{l}1 \text { jam setelah pemberian } \\
\text { osmoterapi }\end{array}$} \\
\hline Mean \pm Std & $116,92 \pm 17,380$ & $123,46 \pm 18,025$ & $131,15 \pm 26,981$ & 0,269 \\
\hline \multicolumn{5}{|l|}{ Saat Duramater Dibuka } \\
\hline Mean \pm Std & $134,00 \pm 29,586$ & $126,23 \pm 21,506$ & $166,53 \pm 30,231$ & $0,001 * *$ \\
\hline
\end{tabular}

Keterangan: untuk data numerik nilai p diuji dengan uji One Way Anova apabila data berdsitribusi normal, dengan alternatif uji Kruskal Wallis apabila data tidak berdistribusi normal. Data kategorik nilai p dihitung berdasarkan uji Chi-Square dengan alternatif uji Kolmogorov Smirnov dan Exact Fisher apabila syarat dari Chi-Square tidak terpenuhi. Nilai kemaknaan berdasarkan nilai $\mathrm{p}<0,05$. Tanda* menunjukkan nilai $\mathrm{p}<0,05$ artinya signifkan atau bermakna secara statistik. 
Natrium laktat hipertonik memiliki nilai median yang sama besar (2,00; Tabel 3), menggambarkan tidak adanya perbedaan BRS yang signifikan antara ketiga kelompok perlakuan. Terdapat perbedaan yang signifikan pada nilai klorida dari ketiga kelompok osmoterapi pada 1 jam setelah pemberian osmoterapi dan saat duramater dibuka $(\mathrm{p}<0,05)$. Pada hasil uji statistika dari kelompok $\mathrm{NaCl} 3 \%$ terdapat peningkatan nilai klorida yang berbeda secara signifikan disbanding dengan kelompok mannitol $20 \%$ dan natrium laktat hipertonik ( $p<0,05$; Tabel 4). Berdasarkan analisis statistika terdapat perbedaan peningkatan nilai glukosa darah yang bermakna pada saat duramater dibuka antara ketiga kelompok. Peningkatan kadar glukosa darah yang signifikan terjadi saat duramater dibuka pada kelompok natrium laktat hipertonik ( $<<0,05$; Tabel 5).

Hasil uji statistika pada perbandingan rerata urin terdapat perbedaan yang signifikan antara ketiga kelompok osmoterapi $(\mathrm{p}<0,05)$. Urin terbanyak didapatkan pada kelompok mannitol $20 \%$ dibanding dengan $\mathrm{NaCl} 3 \%$, dan natrium laktat hipertonik dengan rata-rata sebesar $1984,61 \pm 393,374$ cc, $788,46 \pm 173,390$ cc dan $800,00 \pm 156,790 \mathrm{cc}(\mathrm{p}=0,000)$.

\section{Pembahasan}

Otak yang relaks untuk pembedah merupakan salah satu tujuan penting pada manajemen anestesi pada pasien yang menjalani kraniotomi. Otak yang relaks memudahkan manipulasi surgikal sehingga kerusakan jaringan otak sehat lebih sedikit dan luaran neurologi pasien lebih baik. Peningkatan tekanan intrakranial dapat mengakibatkan otak yang tegang intraoperatif. Penatalaksanaan medikal edema serebral dan peningkatan tekanan intrakranial dengan osmoterapi merupakan komponen penting dalam manajemen perioperatif dalam bedah saraf. Tujuan osmoterapi adalah untuk menjaga normovolemia atau sedikit hipervolemia dengan osmolaritas antara 300 dan $320 \mathrm{mOsm} / \mathrm{L}$ sehingga membutuhkan monitoring selama terapi. ${ }^{1-3}$

Pada penelitian ini dilakukan pemberian cairan hiperosmolar, yaitu mannitol $20 \%, \mathrm{NaCl} 3 \%$, dan natrium laktat hipertonik pada 39 pasien yang menjalani operasi kraniotomi pengangkatan tumor elektif di Rumah Sakit Umum Pusat Dr. Hasan Sadikin. Hasil penelitian didapatkan osmolaritas plasma sebelum osmoterapi, 1 jam setelah pemberian osmoterapi, dan saat duramater dibuka tidak didapatkan perbedaan peningkatan osmolaritas yang signifikan antara kelompok mannitol 20\%, $\mathrm{NaCl} 3 \%$, dan natrium laktat hipertonik. Hal ini sesuai dengan penelitian yang dilakukan di Amerika pada tahun 2007 membandingkan efek serebral mannitol 20\% dan $\mathrm{NaCl} 3 \%$ membuktikan bahwa terjadi peningkatan osmolaritas plasma yang sama pada kedua kelompok dan tidak didapatkan perbedaan pada penurunan TIK antara kedua kelompok. Perbedaan osmolaritas yang tidak bermakna disebabkan oleh osmolaritas yang tidak berbeda secara signifikan antara mannitol, $\mathrm{NaCl} 3 \%$ dan natrium laktat hipertonik, yaitu $1100 \mathrm{mOsm} / \mathrm{L}$, $1026 \mathrm{mOsm} / \mathrm{L}$, dan $1020 \mathrm{mOsm} / \mathrm{L} .{ }^{8,10}$

Hal lain yang dinilai pada penelitian ini adalah Brain relaxation score (BRS). BRS adalah penilaian relaksasi otak yang dilakukan oleh pembedah segera setelah membuka duramater yang memiliki 4 skor, yaitu: 1 (Relaks sempurna yang ditandai dengan parenkim otak tidak melekat pada duramater), 2 (Cukup relaks yaitu parenkim otak melekat pada duramater namun masih relaks, 3 (Tegang atau parenkim otak sedikit menonjol) dan 4 (Cembung di mana parenkim otak menonjol ke luar duramater). Nilai BRS pada ketiga kelompok penelitian ini tidak memiliki perbedaan yang signifikan. Hal ini menggambarkan relaksasi otak yang baik dengan pemberian ketiga jenis osmoterapi tersebut. Hasil penelitian ini sejalan dengan penelitian sebelumnya yang membandingkan mannitol 20\% dan NaCL 3\% serta penelitian yang membandingkan mannitol $20 \%$ dan natrium laktat hipertonik. ${ }^{2,11-13}$

Penelitian sebelumnya yang dilakukan pada tahun 2007 pada 40 pasien di Amerika Serikat yang menjalani operasi kraniotomi karena berbagai penyebab neurologis membandingkan penggunaan mannitol dan $\mathrm{NaCl}$ hipertonik terhadap relaksasi otak dan balans elektrolit. Penelitian tersebut menyatakan bahwa mannitol dan $\mathrm{NaCl}$ hipertonik memberikan efek yang sama terhadap relaksasi otak yang dinyatakan dengan 
BRS. ${ }^{10}$ Penelitian yang dilakukan di Makassar terhadap 42 pasien dengan COT sedang pada tahun 2012 membandingkan efektivitas Na laktat dan Mannitol terhadap relaksasi otak dan kadar glukosa, menunjukkan bahwa natrium laktat hipertonik memberikan relaksasi otak yang sama dibanding dengan mannitol 20\% namun dengan profil hemodinamik yang lebih stabil. Walaupun demikian, peningkatan kadar glukosa yang signifikan juga terjadi pada kelompok pasien yang diberikan natrium laktat hipertonik. ${ }^{7}$

Namun pada beberapa penelitian lain, mengungkapkan bahwa $\mathrm{NaCl} 3 \%$ dan natrium laktat hipertonik memberikan relaksasi otak yang lebih baik, yaitu pada penelitian di India tahun 2014 terhadap 114 pasien yang menjalani kraniotomi tumor supratentorial elektif menyatakan bahwa $\mathrm{NaCl}$ 3\% hipertonik memberikan relaksasi otak yang lebih baik dibanding dengan mannitol yang diukur dengan BRS dan penelitian prospektif dengan randomisasi dan buta ganda (double blind) di Taiwan terhadap 106 pasien yang menjalani operasi kraniotomi elektif karena tumor otak supratentorial membandingkan efek mannitol dan $\mathrm{NaCl} 3 \%$ terhadap relaksasi otak menunjukkan hal yang sama. ${ }^{1,14}$ Hal ini dapat disebabkan oleh jumlah subjek penelitian yang lebih sedikit pada penelitian ini. Pada penelitian di India, penelitian dilakukan pada 114 pasien yang menjalani operasi tumor otak supratentorial, begitu juga pada penelitian di Taiwan dimana jumlah sampel penelitian berjumlah 106 pasien. ${ }^{1,9}$

Pemberian $\mathrm{NaCl} 3 \%$ dapat mengakibatkan peningkatan nilai klorida. Tingginya klorida dalam darah dapat mengakibatkan asidosis hiperkloremik dan dapat berpengaruh terhadap luaran pasien. Pengukuran nilai klorida dilakukan pada penelitian ini yaitu sebelum dan 1 jam setelah pemberian osmoterapi serta saat duramater dibuka. Nilai klorida sebelum osmoterapi tidak ada perbedaan bermakna antara ketiga kelompok $(p>0,05)$. Setelah 1 jam pemberian osmoterapi perbandingan antara nilai klorida pada kelompok mannitol 20\%, $\mathrm{NaCl} 3 \%$ dan natrium laktat hipertonik yaitu 103,07 $\pm 4,071,107,69 \pm 3,923$, $102,53 \pm 3,799(\mathrm{p}=0,003)$. Saat duramater dibuka pada kelompok mannitol 20\%, $\mathrm{NaCl} 3 \%$ dan natrium laktat hipertonik rerata nilai klorida yaitu $102,38 \pm 2,328,109,07 \pm 3,904,103,07 \pm 3,662$ $(\mathrm{p}=0,000)$. Hal ini menggambarkan terjadinya peningkatan klorida yang signifikan pada kelompok $\mathrm{NaCl} 3 \%$ yaitu 107,69 $\pm 3,923$ (1 jam setelah pemberian osmoterapi), dan 109,07 $\pm 3,904$ (saat duramater dibuka). Sebuah studi prospektif di Brazil tahun 2009 yang dilakukan selama 5 bulan mengevaluasi kejadian hiperkloremia pascaoperasi pada 393 pasien yang dilakukan operasi dan pada kelompok pasien dengan kadar klorida $>114 \mathrm{meq} / \mathrm{L}$ memiliki insidensi asidosis metabolik yang lebih tinggi dan angka mortalitas yang lebih tinggi dengan $\mathrm{p}=0,001$. Pada penelitian ini meskipun terdapat peningkatan nilai klorida yang signifikan pada kelompok $\mathrm{NaCl} 3 \%(109,07$ $\pm 3,904)$ namun tidak mengakibatkan gangguan klinis yang bermakna. Peningkatan nilai klorida yang signifikan pada kelompok pemberian $\mathrm{NaCl}$ 3\% disebabkan pada larutan ini terapat jumlah klorida yang tinggi yaitu $\mathrm{Cl}-513 \mathrm{mEq} / \mathrm{L} .^{7,13,15}$ Pemberian natrium laktat hipertonik sebagai osmoterapi dapat memberikan efek samping peningkatan glukosa darah. Hal ini ditemukan pada penelitian yang dilakukan di Perancis dan Makasar sebelumnya dimana terjadi peningkatan gula darah yang signifikan setelah pemberian natrium laktat hipertonik disbanding dengan kadar gula darah pada pemberian mannitol $20 \%$. Hiperglikemia dipercaya dapat memperburuk luaran neurologis pasien, namun mekanisme tersebut belum jelas. Sebuah hipotesis menyatakan bahwa penumpukan glukosa di sistem saraf pusat mengakibatkan substrat tambahan untuk memproduksi asam laktat saat periode iskemik dan peningkatan laktat intraseluler memiliki efek neurotoksik yang menyebabkan kematian neuron. Pada studi klinis, hiperglikemia yang berhubungan dengan penurunan luaran neurologis setelah cedera otak traumatik, stroke iskemia akut, dan perdarahan subarakhnoid adalah bila glukosa $<200 \mathrm{mg} / \mathrm{dl}^{8}{ }^{8-10}$

Glukosa darah pada penelitian ini diukur sebelum pemberian osmoterapi, 1 jam setelah pemberian osmoterapi, dan saat duramater dibuka. Glukosa darah sebelum pemberian osmoterapi didapatkan tidak ada perbedaan yang signifikan $(p>0,05)$. Glukosa darah setelah 1 jam pemberian osmoterapi kelompok mannitol 
$20 \%$ memiliki rata-rata sebesar $116,92 \pm 17,380$, kelompok $\mathrm{NaCl} 3 \%$ sebesar 123,46 $\pm 18,025$ dan kelompok Natrium laktat hipertonik sebesar $131,15 \pm 26,981(p=0,269)$. Glukosa Darah saat durameter dibuka pada kelompok Mannitol 20\%, $\mathrm{NaCl} 3 \%$ dan natrium laktat hipertonik, yaitu $134,00 \pm 29,586,126,23 \pm 21,506$, dan 166,53 $\pm 30,231(\mathrm{p}=0,001)$. Peningkatan glukosa darah secara signifikan pada pemberian Natrium laktat hipertonik dengan nilai rerata $166,53 \pm 30,231$ $\mathrm{mg} / \mathrm{dL}$ yaitu saat duramater dibuka. Meskipun terjadi peningkatan, nilai glukosa pada pasien yang diberikan natrium laktat hipertonik masih di bawah $200 \mathrm{mg} / \mathrm{dL}$. natrium laktat hipertonik adalah larutan natrium dan laktat yang didesain secara spesifik agar memiliki osmolaritas yang sama dengan mannitol 20\%. Peningkatan nilai glukosa darah yang signifikan pada kelompok dengan pemberian natrium laktat hipertonik dikarenakan larutan ini mempunyai kandungan laktat $504.1 \mathrm{mmol} / \mathrm{L}$. Laktat dikenal sebagai kunci metabolit interseluler atau interorgan antara glikolisis dan fosforilasi oksidatif yang dapat diproduksi dan digunakan oleh otak dalam kondisi patologis. Penelitian pada hewan dan manusia menunjukkan bahwa laktat dapat mencegah efek neurologis hipoglikemia, mengindikasikan bahwa laktat sistemik dapat dimetabolisme oleh otak. ${ }^{9,16,17}$

Padapenelitian sebelumnyayang membandingkan pemberian mannitol 20\% dan $\mathrm{NaCl} 3 \%$ ataupun natrium laktat hipertonik mengemukakan bahwa pada kelompok mannitol didapatkan diuresis yang lebih banyak. ${ }^{1,9,18}$ Diuresis yang banyak dapat mengakibatkan hipovolemia durante operasi dan menyebabkan gangguan elektrolit pascaoperasi. Perbandingan urin antara kelompok Mannitol $20 \%, \mathrm{NaCl} 3 \%$, dan natrium laktat hipertonik dengan rata-rata sebesar $1984,61 \pm 393,374$ cc, $788,46 \pm 173,390 \mathrm{cc}$ dan $800,00 \pm 156,790$ cc $(\mathrm{p}=0,000)$. Urin terbanyak didapatkan pada kelompok mannitol 20\%.

\section{Simpulan}

Pemberian osmoterapi mannitol 20\%, $\mathrm{NaCl} 3 \%$, dan natrium laktat hipertonik dengan dosis $2,5 \mathrm{~mL} /$ $\mathrm{kgBB}$ memberikan peningkatan osmolaritas plasma dan relaksasi otak yang sama. Pemilihan osmoterapi dapat disesuaikan dengan keadaan klinis pasien karena efek samping yang berbeda pada setiap pemberian osmoterapi (hiperkloremia pada pemberian $\mathrm{NaCl} 3 \%$, hiperglikemia pada pemberian natrium laktat hipertonik, dan diuresis yang banyak pada pemberian mannitol 20\%). mannitol 20\% masih merupakan pilihan pertama dari pemberian terapi osmoterapi karena efek samping yang lebih ringan disbanding dengan $\mathrm{NaCl} 3 \%$ dan natrium laktat hipertonik.

\section{Daftar Pustaka}

1. Malik ZA, Mir SA, Naqash IA, Sofi KP, Wani AA. A prospective, randomized, double blind study to compare the effects of equiosmolar solutions of 3\% hypertonic saline and 20\% mannitol on reduction of brain bulk during elective craniotomy for supratentorial brain tumor resection. Anesth Essays Res. 2014;8(3):388-92.

2. Sankhyan N, Raju KNV, Sharma S, Gulati S. Management of raised intracranial pressure. Indian J Pediatr. 2010;77:1409-16.

3. Forster N, Engelhard K. Managing elevated intracranial pressure. Curr Opin Anaesthesiol. 2004;17:371-6.

4. Bisri T. Pengelolaan hipertensi intrakranial. Seri Buku Literasi Anestesiologi Dasar Dasar Neuroanestesi. Edisi. Bandung: Saga; $2011 ; 60$.

5. Bisri T. Pengelolaan hipertensi intrakranial. Penanganan Neuroanestesia dan Critical Care Cedera Otak Traumatik. Edisi. Bandung: Fakultas Kedokteran Universitas Padjadjaran; 2012;187.

6. Torre-Healy A, Marko NF, Weil RJ. Hyperosmolar therapy for intracranial hypertension. Neurocrit Care. 2012;17:11730.

7. Silva JM, Neves EF, Santana TC, Ferreira UP, Marti YN, Silva JMC. The importance of intraoperative hyperchloremia. Rev Bras 
Anestesiol. 2009;59(3):304-13.

8. Rozet I, Tontisirin N, Muangman S, Vavilala MS, Souter MJ, Lee LA, dkk. Effect of equiosmolar solutions of mannitol versus hypertonic saline on intraoperative brain relaxation and electrolyte balance. Anesth. 2007;107:697-704.

9. Raghava A, Bidkar PU, Prakash S, Hemavathy B. Comparison of equiosmolar concentrations of hypertonic saline and mannitol for intraoperative lax brain in patients undergoing craniotomy. Surg Neurol Int. 2015;6:73-9.

10. Rusa R, Zornow MH. Fluid management during craniotomy. Dalam: Cottrell JE, Young WL, penyunting. Cottrell and Young's Neuroanesthesia. Edisi ke-5. Philadelphia: Mosby Elsevier; 2010; 147-52.

11. Mortazavi MM, Romeo AK, Deep A, Griessenauer CJ, Shoja MM, Tubbs RS, dkk. Hypertonic saline for treating raised intracranial pressure: literature review with meta-analysis. J Neurosurg. 2012;116:21021.

12. Bisri T. Dasar - Dasar Neuroanestesi. Seri Buku Literasi Anestesiologi Dasar - Dasar Neuroanestesi. Edisi. Bandung: Saga; 2011;1-11.

13. Lu Q, Xu M, Zhou JX. Correlation of measured and calculated serum osmolality during mannitol or hypertonic saline infusion in patients after craniotomy: a study protocol and statistical analysis plan for a randomized controlled trial. BMJ open. 2014;4;e004921.

14. Matsumoto M, Sakabe T. Intracranial pressure monitoring. Dalam: Cottrell JE, Patel P, penyunting. Cottrell and Patel's Neuroanesthesia. Edisi ke-6: Mosby Elsevier; 2017;74-9.

15. Sharma RM, Setlur R, Swamy MN. Evaluation of mannitol as an osmotherapeutic agent in traumatic brain injuries by measuring serum osmolality. MJAFI. 2011; 67:230-33.

16. Ichai C, Armando G, Orban J-C, Berthier F, Rami L, Samat-Long C, dkk. Sodium lactate versus mannitol in the treatment of intracranial hypertensive episodes in severe traumatic brain-injured patients. Intensive Care Med. 2008;35(3):471-9.

17. Ahmad MR, Hanna. Effect of equiosmolar solutions of hypertonic sodium lactate versus mannitol in craniectomy patients with moderate traumatic brain injury. Med J Indonesian. 2014;23(1):30-6.

18. Llorente G, Mejia MCNd. Mannitol versus hypertonic saline solution in neuroanaesthesia. Rev Colomb Anestesiol. 2015;43(Suppl 1):29-39. 